\title{
Rehabilitation of historical ruined castles based on field study and laboratory analyses: The case of Bigalı Castle in Turkey
}

\author{
Turgay Cosgun (Main Author) \\ Istanbul University-Cerrahpasa, Department of Civil Engineering \\ 34320, Istanbul (Turkey) \\ costur@istanbul.edu.tr
}

Baris Sayin (Corresponding Author)

Istanbul University-Cerrahpasa, Department of Civil Engineering

34320, Istanbul (Turkey)

barsayin@istanbul.edu.tr

\section{Baris Gunes}

Istanbul University-Cerrahpasa, Department of Civil Engineering

34320, Istanbul (Turkey)

bgunes@istanbul.edu.tr

\section{Ali Osman Avşar}

Restoration-Conservation Centre and Region Laboratory

34122, Istanbul (Turkey)

konservasyon@gmail.com

\section{Rabia Şengün}

MNK Restoration

63100, Şanlıurfa (Turkey)

rabiasengun@gmail.com

\section{Gökhan Gümüşdağ}

Gallipoli Historic Site, Department of Restoration and Construction

17900, Çanakkale (Turkey)

gokhan.gumusdag@kultur.gov.tr

Manuscript Code: 1469

Date of Acceptance/Reception: 13.03.2020/08.05.2019

DOI: 10.7764/RDLC.19.1.52-67

\section{Abstract}

The castle structures, which were designed for defense purposes during the period they were built, as a result of the loss of their functions over time, some of them disappear completely, while some of them survive to the present day as a ruin. The rehabilitation of the structures requires a scientific approach and a knowledge of the cultural background to preserve historical identity of the structures. Utilizing these kinds of specific knowledge and the scientific method, the aesthetic and historical values of the structure can be provided. Rehabilitations require an interdisciplinary approach to gain a full understanding of the construction technique and member properties and, also its material characteristics of the structures based on historical documents. In order to restore such structures to their authentic form and prolong their service life, the historical research that started on the date they were built and continued to the present day should be researched, and the material characteristics of the original structural members should be identified. The present study covers the rehabilitation works carried out on a historical ruined castle that was built as a defensive structure in the early 1800s, but has since lost its structural integrity and authentic form. The study is carried out in four stages, beginning with a research of the historical process of the ruined castle, followed by a field study, laboratory analyses and rehabilitation applications. The historical process of the castle was aimed to identify the structural changes that castle has undergone since its construction, while the field study involves a visual examination of the structural defects and the gathering of representative samples from different points of the structure. The laboratory analyses involve mechanical and density tests as well as chemical and mineralogical analyses on the gathered samples. At the last stage, rehabilitation applications were carried out based on the data obtained in the first three stages. In the scope of application works, the joint losses and abrasions to the castle walls was repaired using mixtures formulated through laboratory analyses, and degraded stones was replaced, taking into account their authentic form. Structural cracks were filled following the properties of the original materials. In the completion applications, the abraded and ruptured stones of the castle were completed taking into account the original sizes, types, construction techniques and masonry forms of the stones. As a result of all of the applications, the castle structure was rehabilitated to its authentic situation from ruin, allowing it to survive as an asset of cultural heritage. The study can be deemed important based on its focus on the geometric and material restoration of historical castles that have lost their structural integrity and authentic form, but also in its examination of a defensive structure that was built on the coast of the Aegean Sea in the Dardanelles. 
Historical structures are not only architectural work of art, but also substantial witnesses and documents of old traditions, masterships, technologies and materials (Uğurlu, 2009). Similarly, ruined structures, while they may be seen as having little or no economic value in themselves, in fact have incalculable value as tangible historical records of those who have gone before us, of the lives they lived and of their aspirations and achievements (Donnelly, 2010). Thereby, each structure provides unique and irreplaceable evidence of the past and should be passed on to future generations with that evidence intact, e.g. Colloseum, Italy. In this scope, the purpose of the rehabilitation studies for the structures is to transform into their original state and transfer them to future generations. Above all, as each historic structure is unique, each requires an individual assessment of its significance, its condition and a solution to the particular conservation issues that have arisen. The rehabilitation of ruins requires highly specialized skills in all aspects of the works. Expert advice is needed in assessing the extent of works required, designing and specifying those works and overseeing the project on site. Ruins are the surviving remnants of structures whose function came to an end sometime in the last fifteen centuries. In many cases, these remnants bear witness to the manner of that end: for some it was environmental effects, e.g. volcanic eruption; for others it was violent, e.g. World Wars, through deliberate destruction or through a political act, e.g. invasion. The rehabilitation of masonry ruins presents a multitude of challenges-lack of knowledge about the structure, duration- and cost-issues etc.- to the architect, surveyor, engineer or heritage professional (Donnelly, 2010; Heywood, 1982).

Several researches have been performed to investigate the historical castles (Ashurst \& Ashurst, 1988; Avent, 2011; Ashurst, 2007; Beckmann \& Bowles, 2004; Betti et al., 2011; Binda et al., 2000; Corradi et al., 2002; Croci, 1998; Feilden, 2003; Povilaityte, 2016; Tiberti et al., 2016). Avent (2011) performed that some of the challenges faced in the stabilization of ruins. An approach proposed regarding the process from initial survey through to the implementation of remedial works. It covers the approach to dealing with ruined masonry structures and the need to understand the structure before embarking on conservation strategies. The study enabled these structures to be preserved with minimum intervention and avoided the need for alternative, more intrusive solutions. Betti et al. (2011) investigated an issue of modelling and analysis of architectural heritage through a discussion of the Italian Medieval Castle of San Niccolò. In the study, using the finite element method, a 3D numerical model of the castle has been built that has been used to identify the main sources of the damages and assess the effectiveness of the restoration works. It is understood that the structural behavior can indeed reduce the extent of the remedial measures, offering efficient strengthening tools. Povilaityte (2016) discussed that conservation practices and methods of the Lithuanian medieval castles. The research provided a detailed overview of the archival documents related to the Vilnius Upper Castle preservation projects, methods, and problems in the context of the conservation history of the medieval castles. The prospects for the conservation and rehabilitation of the Vilnius Upper Castle and similar objects of the architectural medieval heritage was also discussed.

In the light of the above information, it is presented that rehabilitation process required to rejuvenation of the castle based on historical research, field study and lab analyses. The study that was conducted with this purpose in mind includes the improvement process of a historical ruined castle. The works carried out on the castle that is planned to be opened to the public after the rehabilitation process have been completed include; i. A historical research, ii. Representative material sampling, iii. Mechanical, chemical and mineralogical analyses of the materials of the gathered samples, and iv. Rehabilitation applications. All applications for the rehabilitation of the castle to its authentic form was identified following an assessment of the data obtained from the stages.

Description of the problem

\section{The examined ruined castle}

Çanakkale is an important port city on one of the two straits in Turkey, and is located on the Biga and Gallipoli peninsulas. Bigalı Castle, which is the subject of this study, was built between 1807 and 1820 during the reign of Ottoman emperor Mahmut II. It has a rectangular plan with dimensions of $70 \mathrm{~m} \times 130 \mathrm{~m}$, and is supported by polygonal and circular towers at its corners (Figures 1 and 2).The difference of Bigalı Castle from other castle structures built during the Ottoman period is that it has military headquarters, arsenal depot, mosque and water fountain structures in the castle. Additionally, the castle was not subjected to repair or intervention since its construction. For this reason, the structure was examined within the scope of the study. 
Figure 1. The location of Bigalı Castle. Source: Adapted from Cosgun et al. (2019)
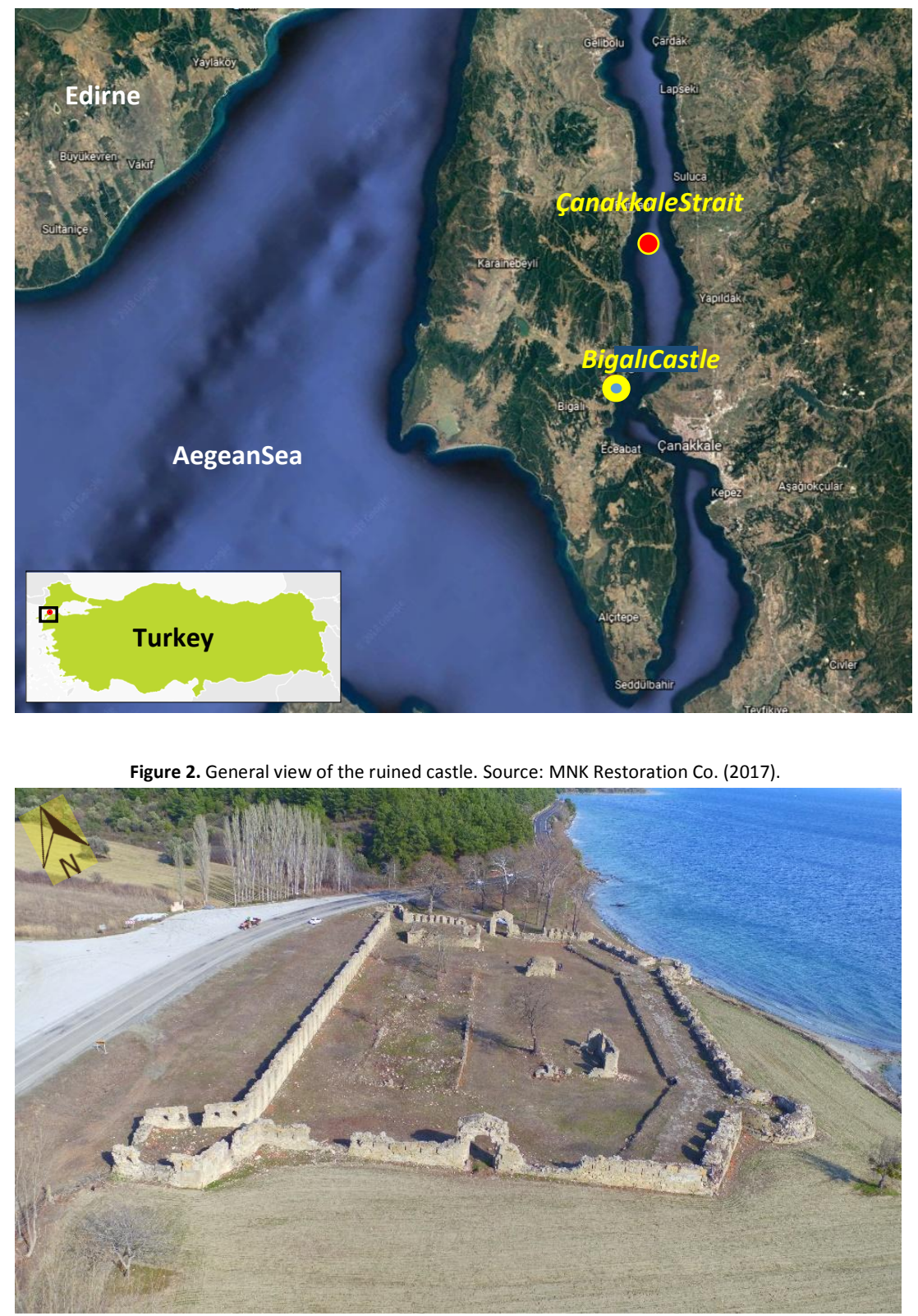

\section{The historical background}

Castles were built in strategic locations to provide defense. In the Ottoman Era, thirteen-castles had been built in accordance with the conditions and technological developments of the time by the middle of the 19th century, with the main purpose of protecting Çanakkale strait and Istanbul against potential attacks from the Mediterranean. The first of these strategic structures was the Anatolian Fortress built in 1390 during the rule of Yıldırım Bayezid, which consists of an outer rampart on the Anatolian shore of the Bosphorus, and an inner rampart in which the main tower is located. In 1452, under the rule of Mehmed the Conqueror, the Rumeli Fortress was built to the right across of Anatolian Fortress for the conquest of Istanbul (Erişmiş \& Gezerman, 2013). The construction of such defensive structures for the control of the Straits continued after Bayezid and Mehmed the Conqueror (Gabriel, 1941; Mirmiroğlu, 1946; Kritovulus, 1967; Ostrogorsky, 1986; Sevgen, 1959; Utkular, 1954; Ayverdi, 1989; Högg, 1932). Similarly, two castles were built on opposite sides of the Dardanelles in 1462, just as in the case in the Bosphorus. However, Selim III appointed French engineer Jochereau de Saint Denys to improve the defense of the strait, which was found to be quite unsatisfactory, particularly after the development of military technologies in the early 19th century. Denys recommended the construction of a castle on Nara Cape and in Bigalı region. When the British navy crossed the Dardanelles and advanced toward Istanbul in 1807, defensive structures started to be built at various locations along the strait, and two of these structures were the castles that had started to be built in the Nara Cape and Bigalı region (Cezar \& Sertoğlu, 2011; Acıoğlu, 2015; Acıoğlu, 2020).The construction of the Bigalı Castle started in 1807 during the reign of Sultan Selim III and was completed in 1820 during the reign of Sultan Mahmut II. The main 
purpose of the castle was control and it was not the scene of wars. During the 1915 Çanakkale Wars, it was used as the 3rd Corps Weapon Repair Unit. It lost its function after the Çanakkale wars and turned into a ruin due to abandonment and environmental effects. While the castle examined in this study was in a good condition and had retained all of its components in the 1890s, it currently comprises a ruined mosque, a water fountain, anarsenal depot and two military headquarters, of which traces of the foundations are still visible (Figures 3 and 4).

The materials used in construction include rubble stone, pitch-faced stones, ashlar, granite, block stone and brick. The entrance to the castle is through two doors located on the same axis in an east-west direction that are higher than the walls of the structures, with one being $3 \mathrm{~m}$ and the other being $2.6 \mathrm{~m}$.

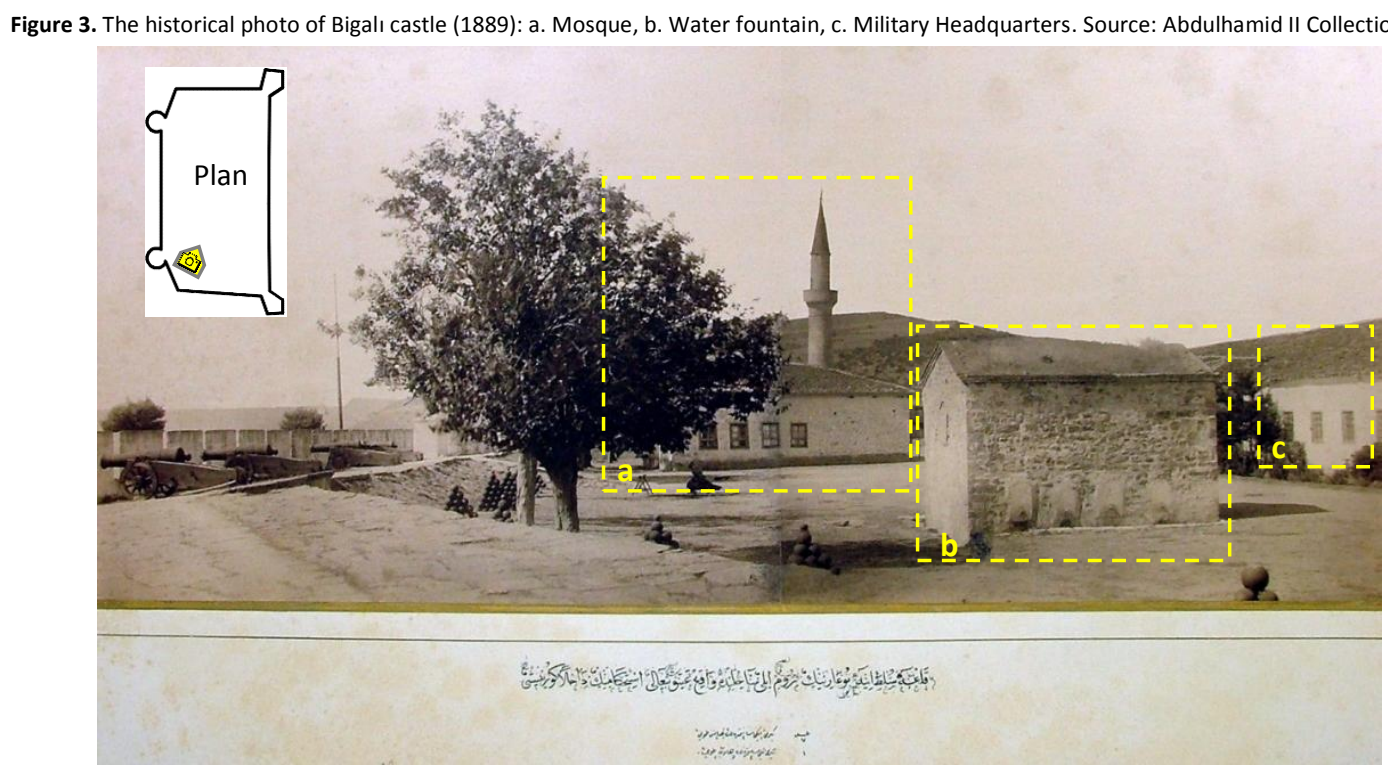

Figure 4. The current view of the ruined castle: a. Facades, b. Circular towers, c. West- and East-entrance, d. Square towers, e. Mosque, $f$ Military headquarters, g. Water fountain, h. Arsenal depot. Source: Authors.

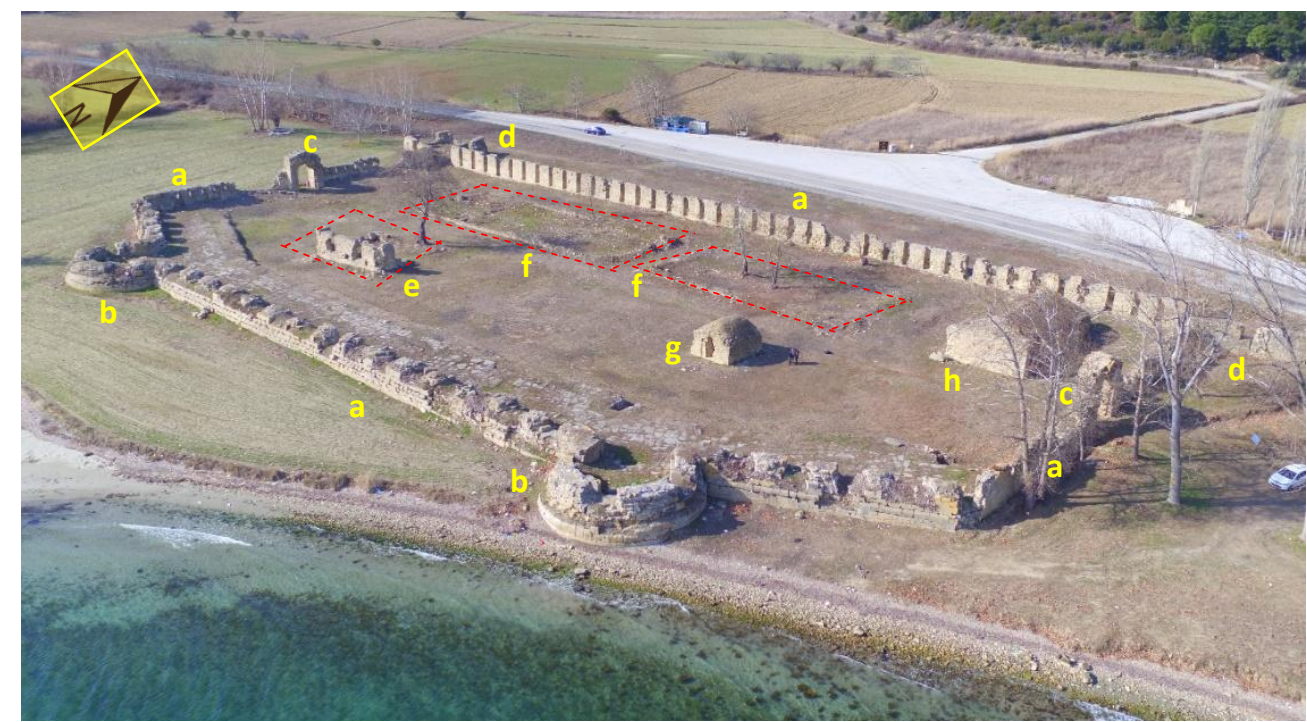

\section{Structural cracks and physical contaminations}

Material losses and defects were determined in many parts of the ruined castle (Figures 5 to 7). The physical and structural defects can be grouped as follows: $i$. Loss of components, ii. Partial collapse, iii. Surface erosion to the stone, iv. Structural cracks, v. Plaster flaking, vi. Joint losses, vii. Vegetations; and viii. Collapse-induced rubble. 
Figure 5. Structural cracks in the south facade walls. Source: Acıoğlu (2013).
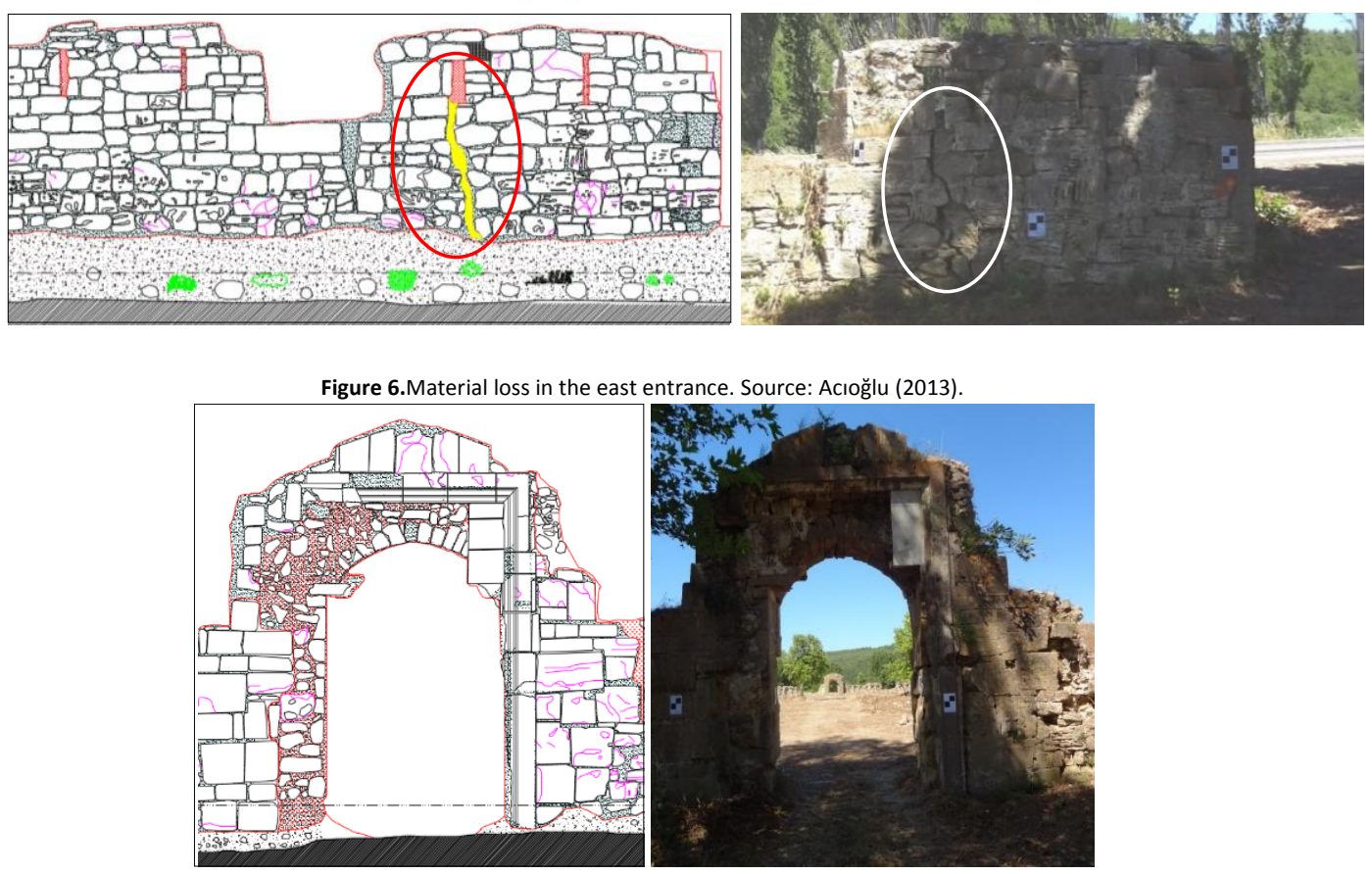

Figure 7.Time-dependent ground settlement in the east facade. Source: Acıoğlu, 2013
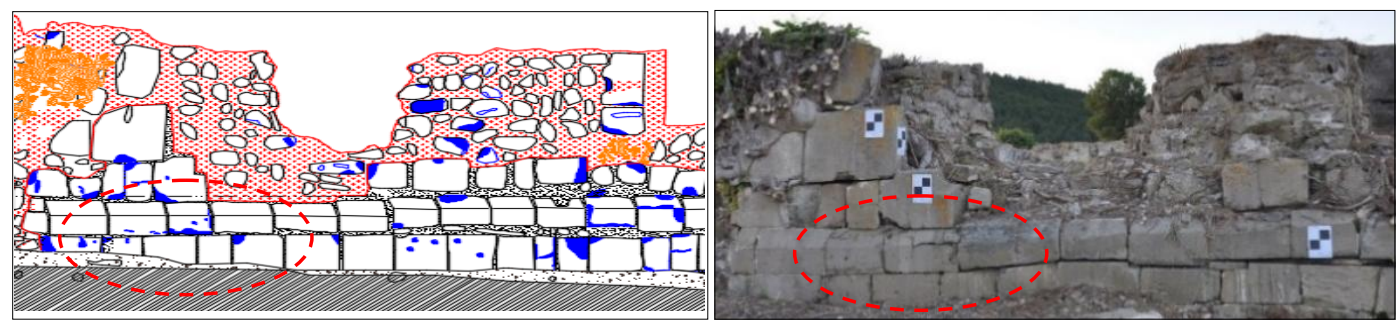

Methodology

\section{Laboratory analyses}

The material properties of the mortar, plaster and stone samples taken from the ruined castle were analyzed in a laboratory, beginning with mechanical and density tests on the natural stone samples, followed by chemical analyses on the plaster and mortar samples.

\section{Mechanical and density tests}

The natural stone (NS) samples taken from the castle were subjected to compressive strength, flexural strength and density tests in accordance with the standards (TS EN 1926, 2013; TS EN 1936, 2010; TS 12372, 2013) (Tables 1 and 2).Therefore, the parts with lack of material in the structure were produced based on these values in accordance with the original.

Table 1. The results of compressive- and flexure-tests. Source: Cosgun et al. (2019).

\begin{tabular}{ccccccc}
\multicolumn{7}{c}{ Table 1. The results of compressive- and flexure-tests. Source: Cosgun et al. (2019). } \\
\cline { 2 - 3 } Sample & $\begin{array}{c}\text { For compressive } \\
\mathrm{a} \times \mathrm{b} \times \mathrm{c}\end{array}$ & $\begin{array}{c}\text { For flexure } \\
\mathrm{a} \times \mathrm{b} \times \mathrm{h} \times \mathrm{l}\end{array}$ & & Compressive & Flexure \\
\hline NS1 & $83.8 \times 70.4 \times 73.0$ & $300 \times 73.0 \times 69.9 \times 250$ & & 6.6 & 2.2 \\
NS2 & $80.6 \times 69.7 \times 73.5$ & $300 \times 74.4 \times 70.4 \times 250$ & & 6.9 & 2.7 \\
NS3 & $84.5 \times 70.3 \times 72.6$ & $300 \times 73.1 \times 70.4 \times 250$ & & 7.7 & 2.5 \\
& & Average & & 7.1 & 2.4 \\
\hline
\end{tabular}




\begin{tabular}{ccccccc}
\multicolumn{7}{c}{ Table 2. The results of density test. Source: Cosgun et al. (2019) } \\
\hline * Sample & $\begin{array}{c}\text { Dry } \\
\text { weight } \\
(\mathrm{g})\end{array}$ & $\begin{array}{c}\text { Saturated } \\
\text { unit weight } \\
(\mathrm{g})\end{array}$ & $\begin{array}{c}\text { Weight } \\
\text { in water } \\
(\mathrm{g})\end{array}$ & $\begin{array}{c}\text { Apparent } \\
\text { density } \\
\left(\mathrm{kg} / \mathrm{m}^{3}\right)\end{array}$ & $\begin{array}{c}\text { Open } \\
\text { porosity } \\
(\%)\end{array}$ & $\begin{array}{c}\text { Water } \\
\text { absorption } \\
\text { by mass (\%) }\end{array}$ \\
\hline NS1 & 681.4 & 761.2 & 401.0 & 1892 & 22.15 & 11.71 \\
NS2 & 664.1 & 744.3 & 389.5 & 1872 & 22.60 & 12.08 \\
NS3 & 680.7 & 761.3 & 400.3 & 1886 & 22.33 & 11.84 \\
& & & Average & 1883 & 22.36 & 11.88 \\
\hline
\end{tabular}

${ }^{*}$ The tests are performed for cube samples $(70 \times 70 \times 70 \mathrm{~mm})$

\section{Sampling and visual definition}

A detailed investigation was carried out during which representative samples-authentic materials- were taken from different locations, after first determining that they were part of the original structure, rather than later additionshaving a different appearance and physical feature from the material used throughout the building-. The plaster and mortar samples were examined visually and subjected to chemical and mineralogical tests in accordance with the standards, and water-soluble salt contents of the samples were investigated through simple spot tests. The qualities, content and ratio of binders, aggregates and additives of the samples were identified, and calcination, petrographic analysis and acid loss tests, as well as a visual analysis of the aggregates that did not react with acids under a stereo microscope, were carried out. The codes and locations of the samples are given in Table 3 and Figure 8, with detailed visual descriptions given in Table 4.

\begin{tabular}{ccc}
\multicolumn{3}{c}{ Table 3. The locations of the samples. Source: Authors. } \\
\hline Sample & Material & Location \\
\hline M1a & Mortar & Arsenal depot \\
M1b & Plaster & Arsenal depot \\
M2 & Filler mortar & East entrance \\
M3 & Mortar & Water fountain \\
M4 & Mortar & Facade \\
M5 & Mortar & Facade \\
M6 & Mortar & Facade \\
M7 & Mortar & Facade \\
M8 & Mortar & Facade \\
\hline
\end{tabular}

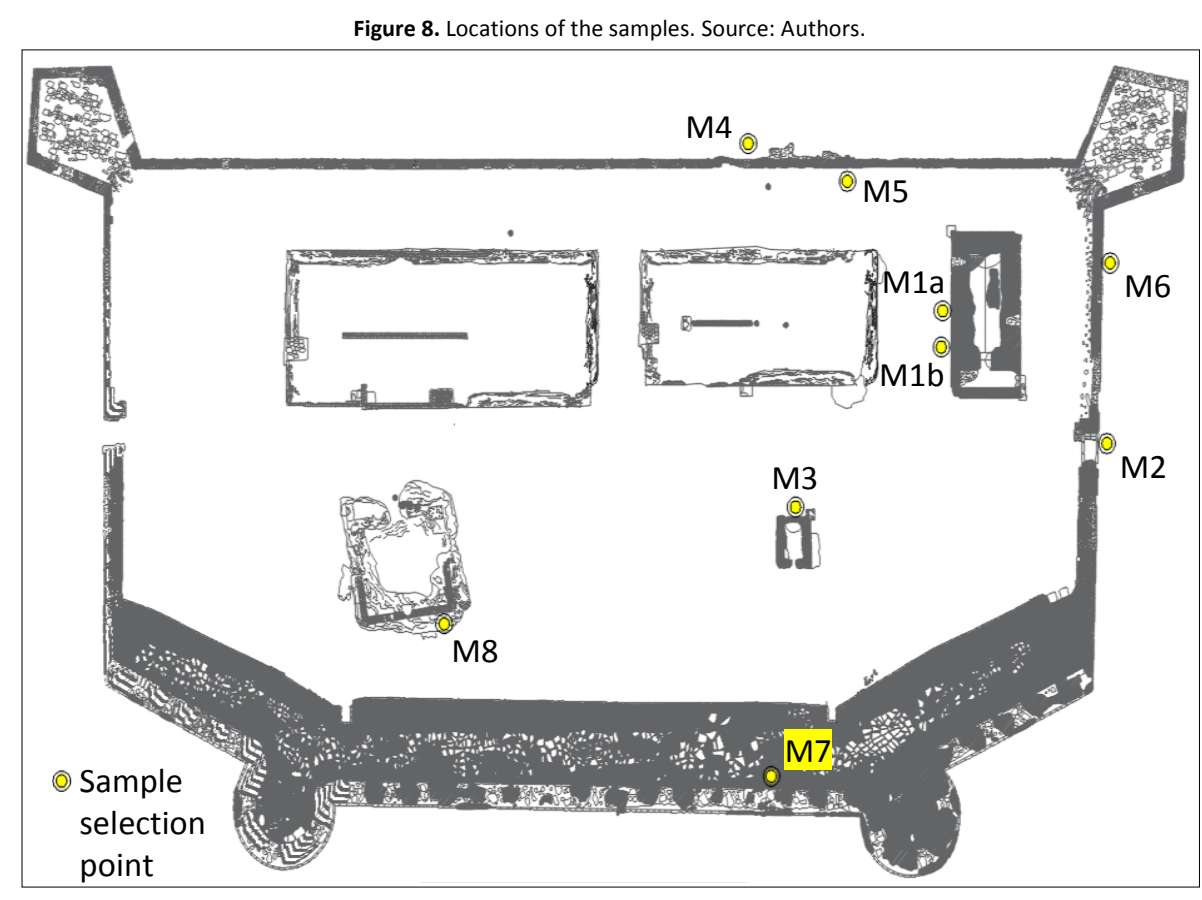




\begin{tabular}{clcc}
\multicolumn{4}{c}{ Table 4. Visual definition of the samples. Source: Authors. } \\
\hline${ }^{*}$ Sample & Durability level & Visual examination & Color in existing condition \\
\hline${ }^{* *}$ M1a & Durable & Creamy white & Mustard yellow \\
M1b & Moderately durable & Creamy white & Mustard yellow \\
M2 & Quite durable & Off-white & Light brown \\
M3 & Quite durable & Off-white & Beige \\
M4 & Quite durable & Off-white & Greenish brown \\
M5 & Quite durable & Off-white & White \\
M6 & Quite durable & Off-white & Brown \\
M7 & Quite durable & Off-white & Mustard yellow \\
M8 & Quite durable & Off-white & Brown \\
\hline
\end{tabular}

With aggregates of various colors and sizes, and with white masses at some locations; ${ }^{* *}$ A small amount of wadding was observed.

\section{Chemical analyses}

In order to determine the chemical properties and aggregate morphology of the mortar and plaster samples, firstly water-soluble salt analysis is performed. Secondly, an acid loss analysis was conducted, followed by sieve analyses and calcination analyses on the aggregates left over from the acid loss analysis.

\section{Water-soluble salt analysis}

Determination of the chemical, mineralogical composition and amounts of salts dissolved in mortars and plasters is important in terms of their deterioration problems. Salt ratios are obtained by determining the conductivity values of water-soluble salts. The ions and their amounts in the dissolved salts are determined by spot tests. Therefore, in an attempt to identify the characteristics of the water-soluble salts contained within the samples, simple spot tests and conductivity measurements were carried out (Table 5).Chloride was detected in all of the tested mortar and plaster samples, and this may be a result of brick ballast used as aggregate; and it is also projected to be carried by bricks present in wall masonry. No sulphide salts were encountered in any of tested samples. The nitrate salt $\left(\mathrm{NO}_{3}\right)$ detected in all samples -except for $\mathrm{Mla}$ - from sewage or residues of living organisms such as birds and bugs. The chloride (Cl) found in some samples may have come from the brick ballast used as an aggregate or carried by means of the bricks in the masonry.

\begin{tabular}{lccccc}
\multicolumn{7}{c}{ Table 5. Contents of water-soluble salts. Source: Authors. } \\
\hline Sample & $\mathrm{C}$ & $\mathrm{SO}_{4}$ & $\mathrm{NO}_{3}$ & Salt \% & Conductivity $(\mu \mathrm{S})$ \\
\hline M1a & +++ & - & - & 3.11 & 560 \\
M1b & +++ & - & + & 2.34 & 420 \\
M2 & +++ & - & +++ & 3.14 & 564 \\
M3 & ++ & & + & 1.02 & 184 \\
M4 & - & - & + & 0.46 & 82 \\
M5 & - & - & + & 0.61 & 110 \\
M6 & +++ & - & + & 1.70 & 306 \\
M7 & +++ & - & + & 1.96 & 353 \\
M8 & - & - & \pm & 0.50 & 90 \\
\hline
\end{tabular}

-: none, \pm : existence/non-existence, +: a little, ++: present, +++: a lot

\section{Calcination analysis}

Calcination analyses were performed to ascertain the pozzolanic activity of the mortars and plasters. In the calcination analysis of the samples, the amount of calcium-carbonate was assessed from the weight change noted under constantly increasing temperatures, as well as the loss of carbon dioxide, moisture and the amount of organic matter (Table 6). The samples were weighed and cooled in a desiccator after each heating, and the moisture, $550^{\circ} \mathrm{C}$ loss and $\mathrm{CaCO}_{3}$ ratios of the samples were calculated by using the weight difference. It is shifted from the amount of calcium oxide that remained in the crucible to calcium carbonate by way of a stoichiometric calculation according to the reaction noted at $550^{\circ} \mathrm{C}$. 
Table 6. Calcination- and acid reaction-analyses. Source: Authors

\begin{tabular}{lccc}
\hline & \multicolumn{3}{c}{ Table 6. Calcination- and acid reaction-analyses. Source: Authors. } \\
\cline { 2 - 4 } Sample & Humition loss (\%) \\
\hline M1a & 2.34 & Organic loss & Calcination \\
M1b & 1.80 & 7.85 & 32.08 \\
M2 & 4.49 & 8.36 & 44.95 \\
M4 & 1.58 & 9.80 & 39.92 \\
M5 & 1.60 & 5.47 & 49.89 \\
M7 & 2.14 & 2.85 & 42.52 \\
M8 & 3.22 & 4.95 & 46.65 \\
M9 & 1.82 & 7.20 & 45.85 \\
M10 & 1.74 & 5.99 & 46.52 \\
\hline
\end{tabular}

\section{Sieve and acid-loss analyses}

Acid reaction and sieve analyses were carried out to determine the proportions, qualities and size distribution of the silicate aggregates that are not in reaction with the binder and the carbonate-containing aggregates in the mortars and plasters. The amount of aggregates used in the production of mortars and plasters is generally determined by the dissolution of carbonized lime in dilute acid. The particle size distributions of the aggregates are determined by sieve analysis. In this context, the sieve and acid-loss analyses were conducted to identify the ratios, qualities and size distribution of the pozzolanic materials used as both filler and additives, as well as of silicate-containing aggregates other than those containing carbonates and binders in mortars and plasters. The size distribution of the aggregates was weighed individually after being separated by means of a set of sieves in the sieve analysis, and the aggregates were then examined by means of a stereo microscope to identify their visual characteristics, the results of which are presented in Table 7.

Table 7. Results of sieve and acid-loss analyses. Source: Authors.

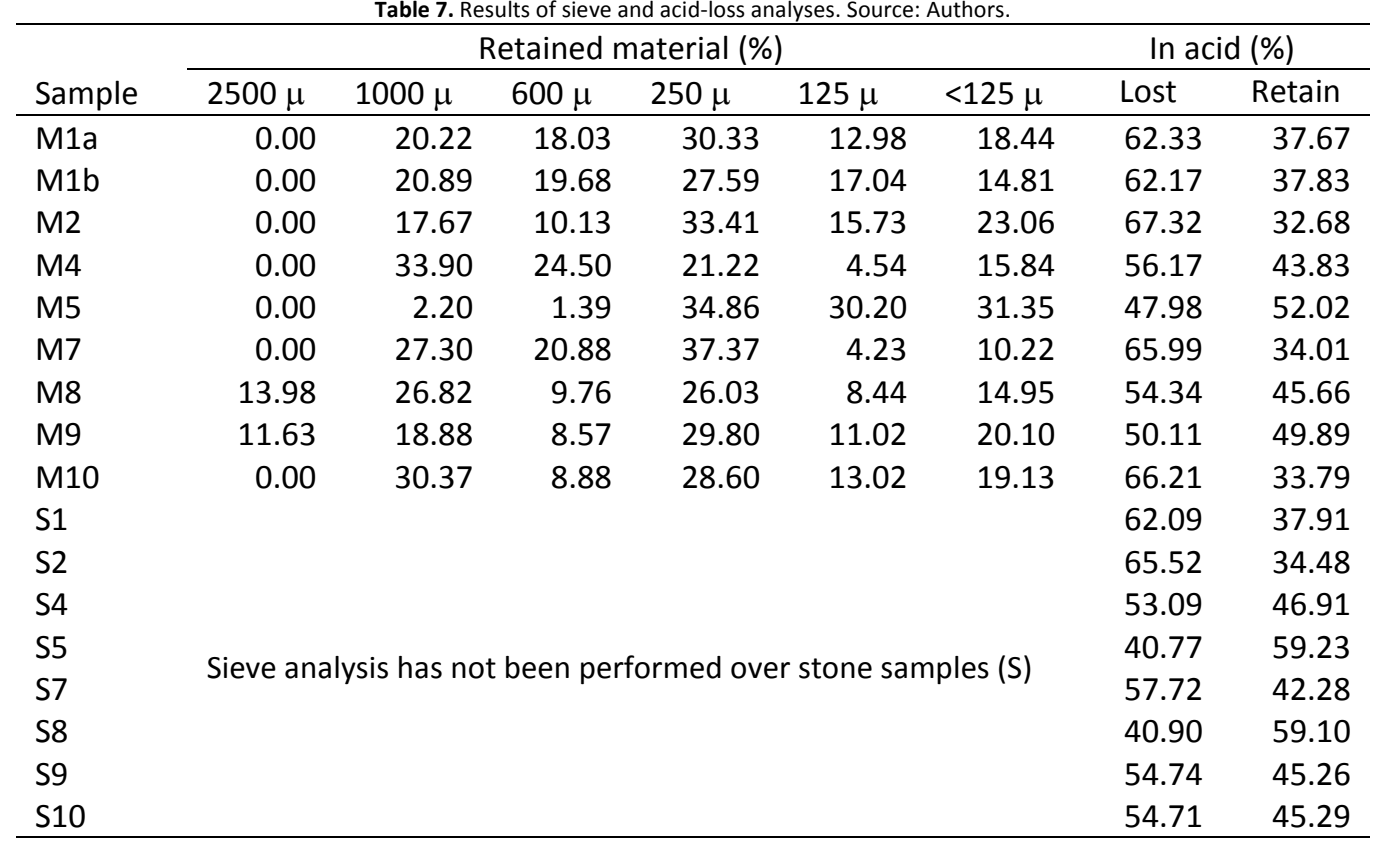

\section{Macro structural properties}

Investigations to determine the macro structural properties of materials are carried out using a stereo microscope and optical microscope. Therefore, the silicate-containing aggregates within the samples whose binders were dissolved through acid treatment, and which did not react to the acid, were grouped in terms of size through a sieve analysis, and were then analyzed under a stereo microscope to identify their visible characteristics, the results of which are presented in Table 8. Examining the stereo microscope analysis results, it is seen that the samples have different characteristics. Based on these data, the material produced in accordance with the original. It is understood that these analyzes are an important step in terms of the effectiveness of rehabilitation. 
Table 8. Stereo microscope analysis. Source: Authors.

\begin{tabular}{|c|c|c|}
\hline Sample & Remains after acid treatment (\%) & General definition \\
\hline M1a & $37.67 \%(20 \%:>1000 \mu, 20 \%:<125 \mu)$ & $\begin{array}{l}\text { Aggregate: Less than } 2 \mathrm{~mm}, 1 \text { piece of } 5-\mathrm{mm} \text { gravel. } \\
\text { Generally gray, a small portion of which is } \\
\text { transparent, angular }\end{array}$ \\
\hline M1b & $37.83 \%(20 \%:>1000 \mu, 15 \%:<125 \mu)$ & $\begin{array}{l}\text { Aggregate: Less than } 3 \mathrm{~mm} \text {, cream, gray, a small } \\
\text { portion of which is transparent, angular }\end{array}$ \\
\hline $\mathrm{M} 2$ & $32.68 \%(40 \%:>250 \mu$ and $<250 \mu)$ & $\begin{array}{l}\text { Aggregate: avg. } 10 \mathrm{~mm} \text {, generally transparent, a } \\
\text { small portion of which is gray, round }\end{array}$ \\
\hline M3 & & $\begin{array}{l}\text { Aggregate: avg. } 2 \mathrm{~mm}, 4 \text { pieces of } 5-\mathrm{mm} \text { gravel. } \\
\text { Generally gray and transparent, round }\end{array}$ \\
\hline M4 & $52.02 \%(61 \%:>250 \mu$ and $<250 \mu)$ & Aggregate: avg. $2 \mathrm{~mm}$, generally gray, round \\
\hline M5 & $34.01 \%(48 \%:>600 \mu)$ & $\begin{array}{l}\text { Aggregate: avg. } 2 \mathrm{~mm}, 3 \text { pieces of } 6-\mathrm{mm} \text { gravel, } \\
\text { generally gray, transparent, a small portion: brick } \\
\text { red, round }\end{array}$ \\
\hline M6 & $45.66 \%$ (27\%: $4 \mathrm{~mm},>1000 \mu ; 14 \%: 8-\mathrm{mm}$ gravel) & $\begin{array}{l}\text { Aggregate: generally gray, transparent, a small } \\
\text { portion: brick red, round }\end{array}$ \\
\hline M7 & 49.89\% (19\%: 5 mm, >1000 $\mu ; 12 \%: 7-m m$ gravel) & $\begin{array}{l}\text { Aggregate: generally gray, transparent, a small } \\
\text { portion: orange, round }\end{array}$ \\
\hline M8 & $33.79 \%$ (30\%: $2 \mathrm{~mm},>1000 \mu ; 12 \%: 7-m m$ gravel) & $\begin{array}{l}\text { Aggregate: } 4 \text { pieces of } 5-\mathrm{mm} \text { gravel, generally gray, } \\
\text { transparent, a small portion: brick red, round }\end{array}$ \\
\hline
\end{tabular}

The textural and aggregate characteristics of the bright (thick) sections prepared using the samples submerged in epoxy were examined under a polarizing microscope (double Nicol prisms) and a stereo microscope (single Nicol prism), and the results are presented in Table 9.

Table 9. Petrography results. Source: Authors.

\begin{tabular}{llll}
\hline \multicolumn{3}{c}{ Table 9. Petrography results. Source: Authors. } \\
\hline Sample & Binder area (\%) & Binder-aggregate-binder phase & Pore \\
M1b & $30-30$ & Good & $\leq 0.5 \mathrm{~mm}:$ Slight amount \\
M2 & $35-40$ & Good & $\leq 0.2 \mathrm{~mm}:$ Slight amount \\
M3 & $35-40$ & Relatively good & $\leq 0.5 \mathrm{~mm}:$ Moderate amount \\
M4 & $30-35$ & Good & $\leq 0.5 \mathrm{~mm}:$ Moderate amount \\
M5 & $30-35$ & Good & $\leq 0.5 \mathrm{~mm}:$ Slight amount \\
M6 & $25-30$ & Relatively good & $\leq 0.5 \mathrm{~mm}:$ Moderate amount \\
M7 & $30-35$ & Relatively good & $\leq 0.5 \mathrm{~mm}:$ Moderate amount \\
M8 & ca. 30 & Weak & $\leq 0.5 \mathrm{~mm}:$ Moderate amount \\
\hline
\end{tabular}

* All samples contain aggregates and freely distributed minerals.

\section{Mineralogical analysis}

A total of seven samples were found to be suitable for mineralogical analyses ( $M 1 a, M 1 b, M 2, M 3, M 5, M 6$ and M7).Each was submerged in epoxy, and thin sections were cut once the epoxy had set. The analyses revealed all the different types of aggregate and the minerals contained within the samples, as well as the binder-aggregate relationship and the porosity of the structure (Table 10). A detailed view of samples M1a and M3 are given in Figure 9. The analyses revealed that the aggregate, mineral composition and texture of mortar samples $M 1 a, M 1 b, M 2, M 3$, M5, M6 and M7 were similar, whereas the samples M3, M5 and M6 contained more coarse-grained aggregated than the other samples. 


\begin{tabular}{|c|c|c|c|c|c|c|c|}
\hline Aggregate and Mineral & M1a & M1b & $\mathrm{M} 2$ & M3 & M5 & M6 & $\mathrm{M7}$ \\
\hline Limestone & $x$ & & $x$ & & & & \\
\hline Limestone (oolitic) & & $x$ & & $x$ & $x$ & $x$ & $x$ \\
\hline Granitic rock & $x$ & $x$ & & $x$ & $x$ & $x$ & $x$ \\
\hline Sandstone & $x$ & & & & $x$ & & \\
\hline Lumps of lime & $x$ & $x$ & & $x$ & & & \\
\hline Quartz & $x$ & $x$ & $x$ & $x$ & $x$ & $x$ & $x$ \\
\hline Quartzite & & & $x$ & $x$ & $x$ & & \\
\hline Feldspar & & $x$ & & $x$ & $x$ & $x$ & $x$ \\
\hline Fossil shell & & $x$ & $x$ & & & & $x$ \\
\hline Iron oxide & $x$ & $x$ & $x$ & $x$ & & $x$ & $x$ \\
\hline Opaque mineral & $x$ & $x$ & & $x$ & $x$ & $x$ & $x$ \\
\hline $\begin{array}{l}\text { Binder-aggregate relationship } \\
\text { Porosity structure }\end{array}$ & $\begin{array}{l}\text { Medium-good } \\
\text { Not defined }^{*}\end{array}$ & $\begin{array}{c}\text { Good } \\
\text { Amorphous pore }\end{array}$ & $\begin{array}{c}\text { Good } \\
\text { Round-shaped }\end{array}$ & & $\begin{array}{r}\mathrm{G} \\
\text { Amo } \\
\end{array}$ & $\begin{array}{l}\text { d } \\
\text { hous }\end{array}$ & \\
\hline
\end{tabular}

* General porosity could not be defined due to ruptures resulting from dissolution.

Figure 9. General view of thin sections: (a,b) Sample M1a, (c,d) Sample M3. Source: Authors.

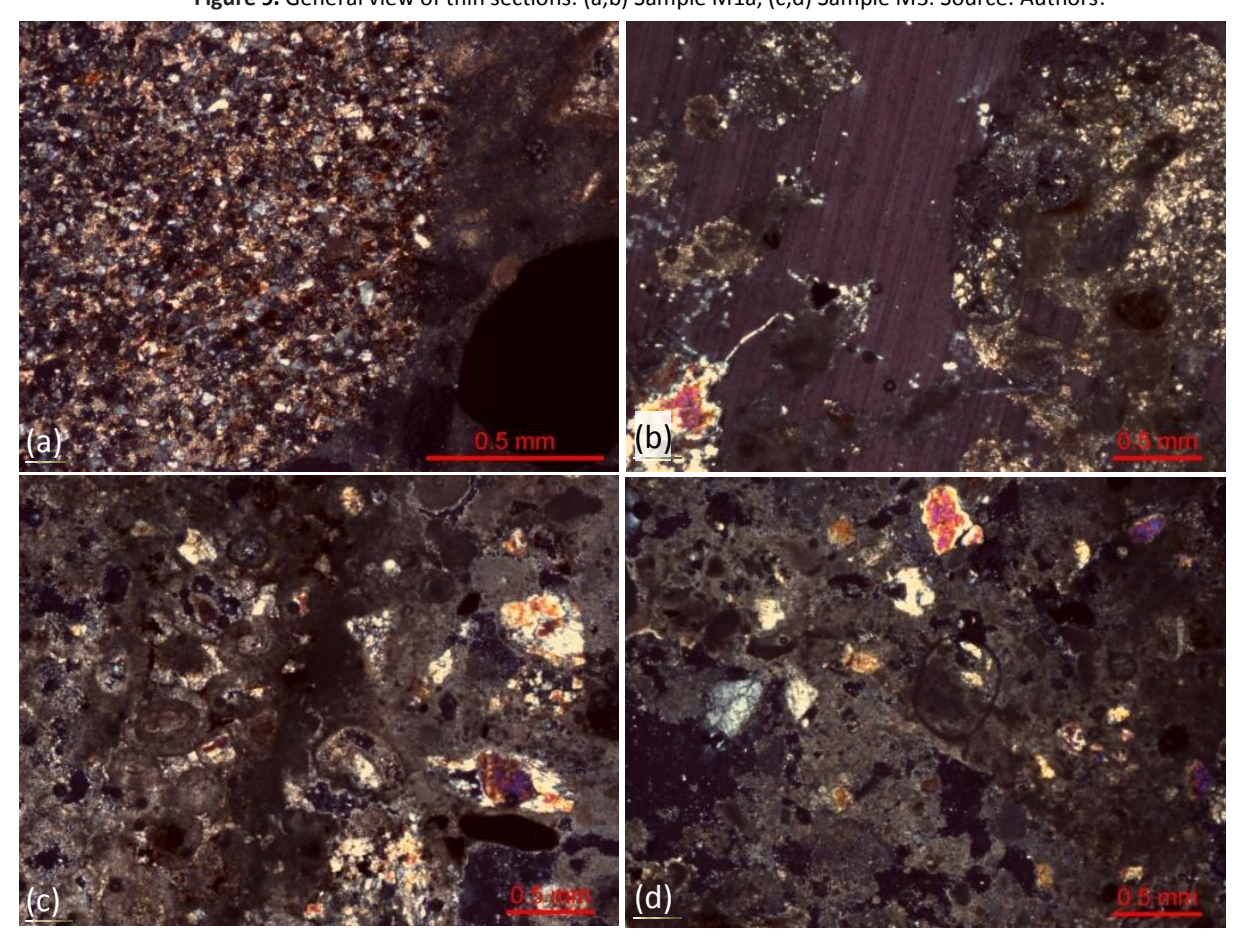

Proposals and Implementations

\section{Suggestions for material mixtures}

The consolidation, integration and repair techniques to be employed for the ruined structure examined in the study were identified based on the data obtained from the laboratory analyses. Taking into account local environmental conditions, the use of hydraulic lime was found to be suitable for use in the five-mixtures formulated for the applications involving mortar. The mixtures corresponding to each sample are presented in Table 11 , and the contents of the five mixtures are detailed in Table 12. 
Table 11. Proposed five-mixtures based on the sample analyses. Source: Authors.

\begin{tabular}{lc}
\hline Sample & Mixture \\
\hline M1 & PM1 \\
M2, M3, M4, M5, M8 & PM2 \\
M6, M7 & PM3 \\
Walk way stone joint & PM4 \\
Cosmetic filling & PM5 \\
\hline
\end{tabular}

Table 12. Proposed lay-up mortar based on the analyses of the samples. Source: Authors.

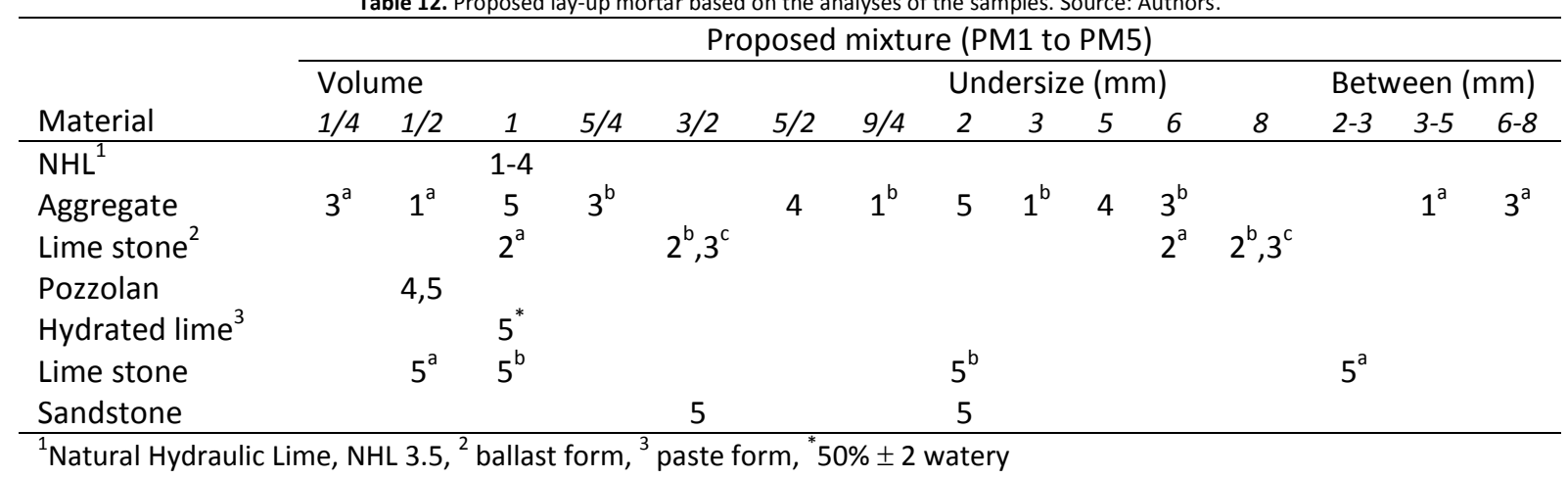

- Jointless and jointed techniques were used on the masonry system of the ruined structure. In areas where joint loss has occurred, mixturePM1 can be used.

- $\quad$ The areas that are likely to retain water on the upper surfaces of the castle walls should be filled with a mortar prepared with mixturePM1, and partial capping should be applied in accordance with the guidelines for ruin repair.

- Classification areas should be created, and the locations of the stone blocks that have fallen from the stone wall should be identified along the walls. All stone elements found during the cleaning works should be numbered and stacked on wooden pallets in these classification areas, close to the wall, and their locations on the wall should be identified. Subsequently, they should be reinstalled using mortar mixtures PM2 and PM3.

- Mixture PM4 should be used for the stone pavement joints on the walkway of the castle.

- Mixture PM5 should be used as a cosmetic filling for the cavities in the sandstone areas of the castle, which may have formed due to surface abrasion over time and may retain water. Before application, they should be cleared of earth and dust to ensure the adherence of the mortar to the surface.

- $\quad$ For surface losses deeper than $5 \mathrm{~cm}$ on certain building blocks, mixture PM5 should be used, and plastic repair or stone replacement should be carried out. This mixture should not be used intensively within the structure, taking into account the desire to protect the historical value of the structure, and so cosmetic repair applications should be used as well.

Based on the assessment of the data obtained from the mechanical and density tests of the stone samples given in Section 3.1, stones with superior mechanical and density characteristics than the original stones in the castle will be used in areas where there are missing or defective stones (Tables 13 and 14).

Table 13. The results of compressive- and flexure-tests of the proposed stone samples. Source: Cosgun et al. (2019).

\begin{tabular}{ccccc}
\hline \multirow{2}{*}{$\begin{array}{c}\text { Proposed } \\
\text { stone }\end{array}$} & \multicolumn{2}{c}{ Dimension $(\mathrm{mm})$} & \multicolumn{2}{c}{ Strength (MPa) } \\
samples & For compressive & For flexure & Compressive & Flexure \\
\cline { 2 - 3 } PS1 & $70 \times 70 \times 70$ & & 23.1 & 6.2 \\
PS2 & $70 \times 70 \times 71$ & $300 \times 47 \times 50 \times 250$ & 20.1 & 4.6 \\
PS3 & $70 \times 71 \times 72$ & 12.8 & 6.6 \\
PS4 & & & 5.6 \\
PS5 & & Average & 5.4 \\
& & 18.7 & 5.7 \\
\hline
\end{tabular}




\begin{tabular}{|c|c|c|c|c|c|c|}
\hline $\begin{array}{l}\text { Proposed } \\
\text { stone } \\
\text { samples }^{*}\end{array}$ & $\begin{array}{c}\text { Dry } \\
\text { weight } \\
\text { (g) }\end{array}$ & $\begin{array}{l}\text { Saturated } \\
\text { unit } \\
\text { weight }(\mathrm{g})\end{array}$ & $\begin{array}{c}\text { Weight } \\
\text { in water } \\
\text { (g) }\end{array}$ & $\begin{array}{c}\text { Apparent } \\
\text { density } \\
\left(\mathrm{kg} / \mathrm{m}^{3}\right)\end{array}$ & $\begin{array}{c}\text { Open } \\
\text { porosity } \\
(\%)\end{array}$ & $\begin{array}{c}\text { Water } \\
\text { absorption } \\
\text { by mass (\%) }\end{array}$ \\
\hline PS1 & 774.4 & 804.9 & 454.7 & 2211 & 8.71 & 3.94 \\
\hline PS2 & 783.4 & 805.7 & 463.0 & 2286 & 6.51 & 2.85 \\
\hline \multirow[t]{2}{*}{ PS3 } & 755.5 & 786.6 & 440.5 & 2183 & 8.99 & 4.12 \\
\hline & & & Average & 2227 & 8.07 & 3.63 \\
\hline
\end{tabular}

${ }^{*}$ The tests are performed for cube stones $(70 \times 70 \times 70 \mathrm{~mm})$.

For the new stones to be used as slabs and stairs, compressive strength and surface abrasion tests were carried out. The compressive strength tests were carried out in accordance with the TS 699 and TS EN 14157 standards (TS 699, 2009; TS EN 14157, 2017); while surface abrasion tests were carried out in accordance with the TS 10449 (2004) standard. Since the compressive and surface abrasion strength values of the samples meet the threshold values in the standards, the stones in question can be considered suitable for use as floor coverings and wall claddings (Table 15).

Table 15. Uniaxial compressive strength of the proposed stone samples. Source:Cosgun et al. (2019).

\begin{tabular}{lcccccc}
\hline \multicolumn{1}{c}{ Test } & $\begin{array}{c}\text { Proposed stone } \\
\text { samples }\end{array}$ & $\begin{array}{c}\text { Dimension } \\
(\mathrm{mm})\end{array}$ & Min. & Max. & Average & Limit \\
\hline Compressive strength $(\mathrm{MPa})$ & PS1 to PS5 & $70 \times 70 \times 70$ & 50 & 75 & 58 & $>30-50^{(2)}$ \\
Surface abrasion loss $\left(\mathrm{cm}^{3} / 50 \mathrm{~cm}^{2}\right)$ & & & 12 & 14 & 13 & $<15-25^{(3)}$ \\
\hline
\end{tabular}

${ }^{1}$ Yellowish white, beige, no pore/slightly porous, highly fossilized limestone, cube form; ${ }^{2} \mathrm{~min} .50 \mathrm{MPa}$, for ground floor; min. $30 \mathrm{MPa}$ for wall cover; ${ }^{3} \max .15 \mathrm{~cm}^{3} / 50 \mathrm{~cm}^{2}$ for ground floor; max. $25 \mathrm{~cm}^{3} / 50 \mathrm{~cm}^{2}$ for wall cover

\section{Rehabilitation Applications}

The applications were carried out on the based on the material mixture proposals for the castle structure. In this context, the rehabilitation stages at the facades were carried out as consolidation, integration, reconstruction and preservation (Figure 10). The views the during- and after-the rehabilitation applications are given in Figures 11 to 14.

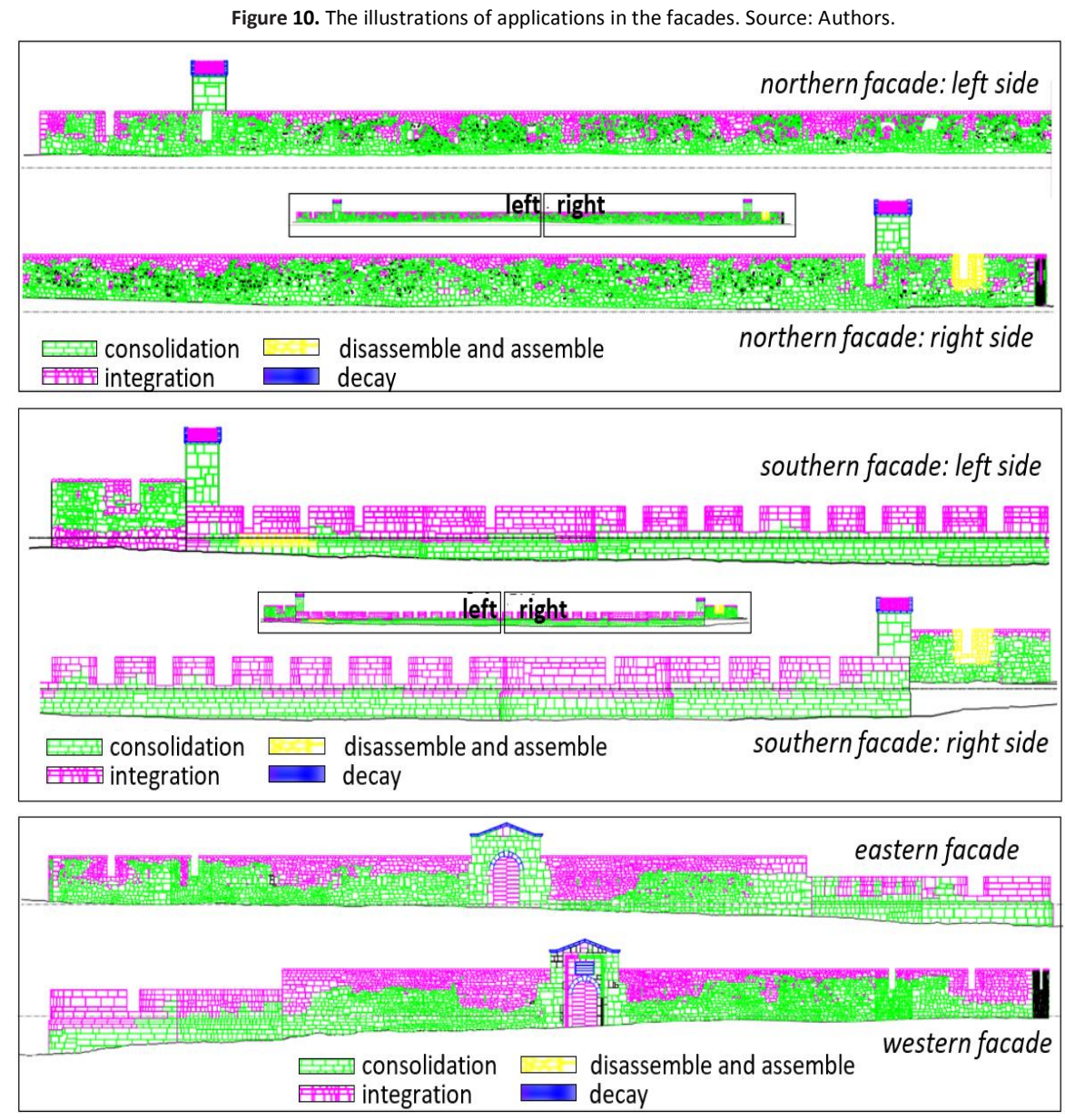


Figure 11. The overview of the castle in the rehabilitation applications: $a$. Facades, $b$. Circular towers, $c$. West- and East-entrance, $d$. Square towers, $e$. Mosque, $f$. Military headquarters, $g$. Water fountain, $h$. Arsenal depot. Source: Authors.

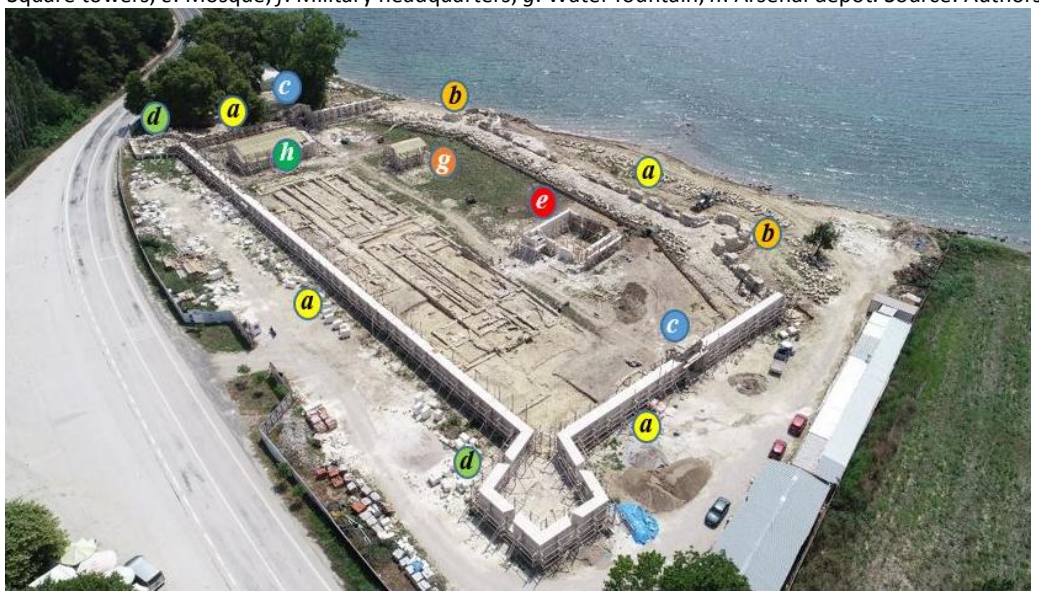

Figure 12. The rehabilitation applications in structures of the ruined castle: $a$. Facades and Circular towers, $b$. East-entrance, $c$. Square towers, $d$. Mosque, e. Arsenal depot, $f$. Water fountain, $g$. Military headquarters. Source: Authors
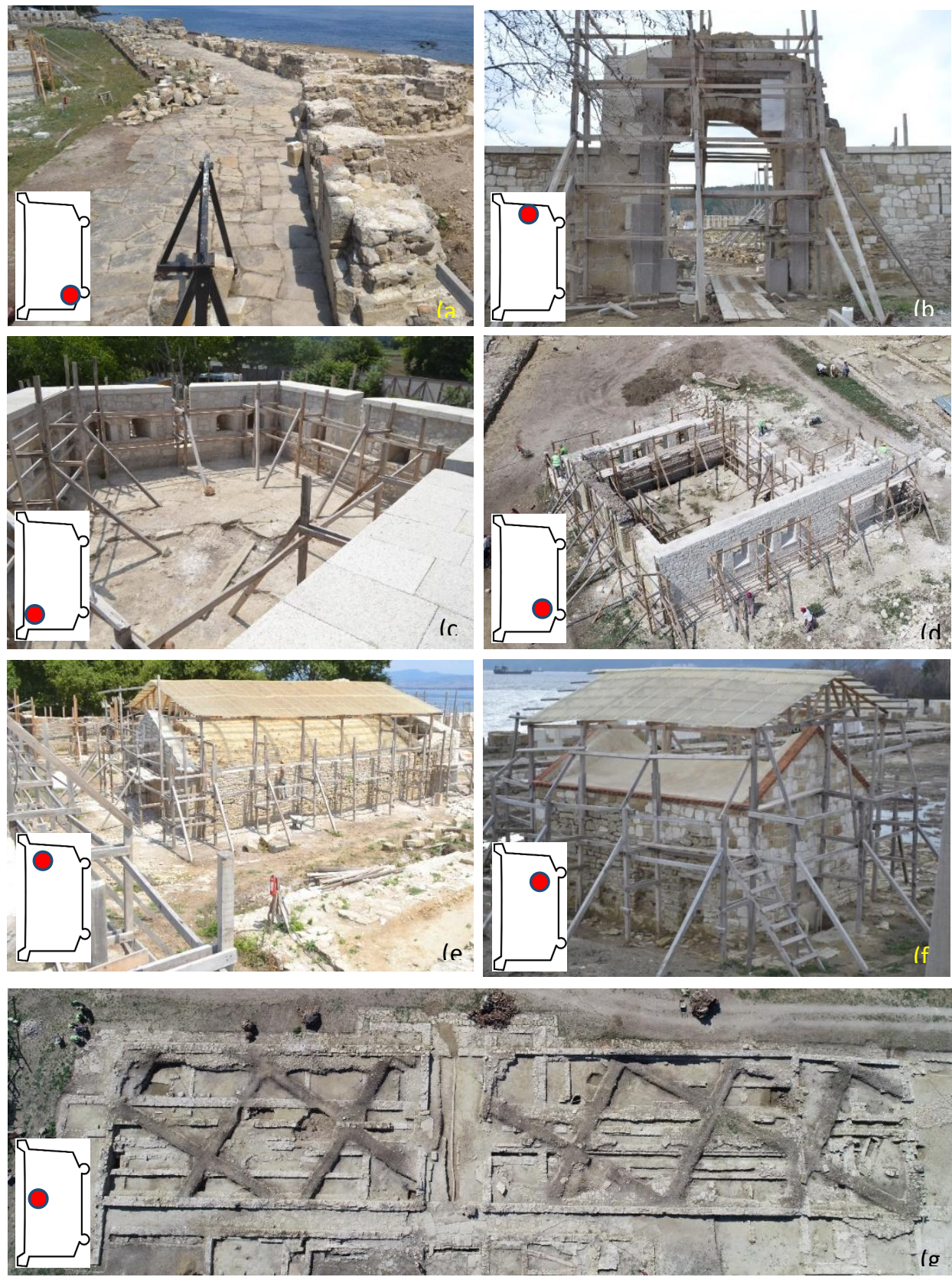
Figure 13. The aerial photo during rehabilitation process. Source: Authors.
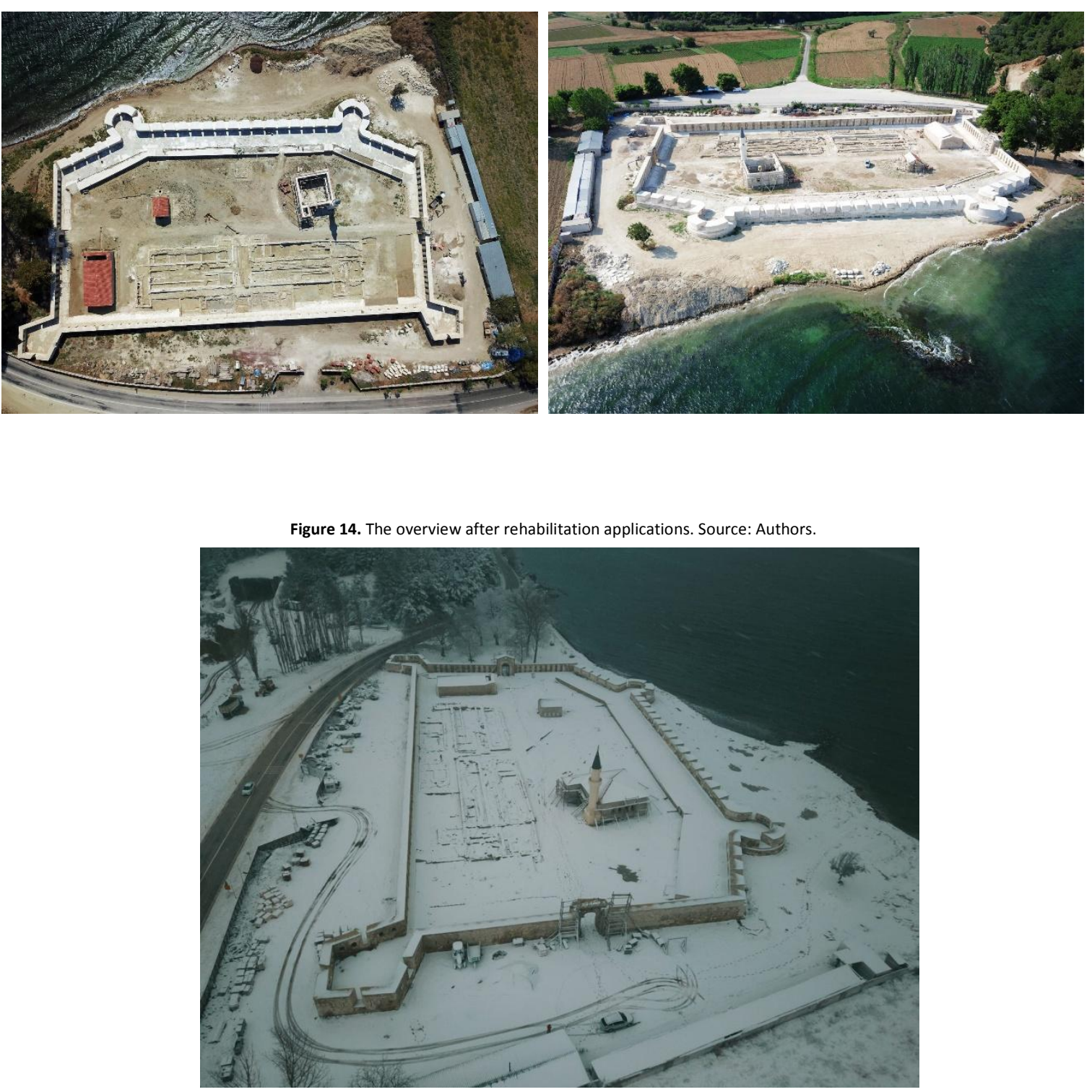

Conclusions

The present study scopes to the rehabilitation process of a historical castle that was built for defensive purposes between 1807 and 1820, but which has lost its functionality over time and has fallen into ruin due to climatic conditions. In order to rehabilitate the ruined castle to its original form and prolong its lifespan by enhancing its resistance to climatic conditions over time, construction, cleaning, consolidation, and integration works was carried out on several parts of the structure. In this scope, all missing or abraded stone walls need to be completed, taking into account the authentic sizes, types, construction techniques and masonry forms of the stones. Among the stones removed from the structure, those that are in good order was improved and used again, whereas rubble that lacks quality was used as a filling material. Within the scope of the consolidation works, the joint losses and abrasions to the castle walls was repaired using mixtures formulated through laboratory analyses, and degraded stones was replaced, taking into account their authentic form. Structural cracks were filled following the properties of the original materials. Within the scope of completion applications, the abraded and ruptured stones of the castle were completed taking into account the original sizes, types, construction techniques and masonry forms of the stones. The soil in the water fountain and arsenal depot that include indoor spaces were removed. Surfaces was cleaned and covered with a waterproofing membrane of mineral-coated polyester felt and mortar. The missing slabs on the floor was replaced, taking into account the original stone characteristics and masonry forms. Joints was filled using the mortar formulated in the laboratory analyses. As a result of all of these applications, the examined historical castle was rehabilitated to its authentic situation from ruin, allowing itto survive as an asset of cultural heritage. In addition to this, as a result of archaeological research in the 
castle; coins, millstones, pipes, ottoman money, weapons pieces, pieces of fabric, terracotta belonging to the Byzantine period, etc. materials were obtained. These antique materials will be exhibited in the museum to be built in the area where the main traces of the military headquarters are located. Besides, in the museums in this region, an inscription belonging to the eastern gate of the castle structure was found and placed in the its gate.

\section{Acknowledgments}

This study was funded by Scientific Research Projects Coordination Unit of Istanbul University-Cerrahpasa (Project numbers: FYD 2016-20949 and FBA-2018-25947).

Abdulhamid II Collection (1889). Istanbul University, Library of rare collection.

Acıoğlu, Y. (2020). Çanakkale Boğazı'ndaki Osmanlı Savunma Yapıları. Eskiçağdan Günümüze Çanakkale Muharebe Alanı. Barış Borlat Ed. Kültür ve Turizm Bakanlığı Yayınları. Ankara, 395-423. (in Turkish)

Acıoğlu, Y. (2015). Çanakkale'deki Osmanlı Kaleleri. Çanakkale Araştırmaları TürkYıllı̆ı. Çanakkale Onsekiz Mart Üniversitesi, Atatürk ve Çanakkale Savaşlarını Araştırma Merkezi Yayını, 13, 19, 93-122 (in Turkish)

Acıoğlu, Y. (2013). Report on Surveying, Restitution, Restoration and Art History for Bigalı Castle, Art-ıMimarlık.

Ashurst, J. \& Ashurst N. (1988). Practical building conservation, Volumes 1, 2 \& 3. Hampshire: Gower Technical Press.

Ashurst, J. (2007). Conservation of ruins, Butterworth-Heinemann, Oxford.

Avent, J. (2011). Conserving and stabilizing masonry ruins, Journal of Architectural Conservation, 17, 1, 29-57.

Ayverdi, E.H. (1989). FatihDevriMimarisi, İstanbul FetihCemiyeti, İstanbul Enstitüsü, Istanbul, 3, 171 (in Turkish)

Beckmann, P. \& Bowles, R. (2004). Structural aspects of building conservation, Butterworth-Heinemann, Oxford.

Betti, M., Orlando, M. \& Vignoli, A. (2011). Static behaviour of an Italian Medieval Castle: Damage assessment by numerical modelling. Computers and Structures, 89,1956-1970. https://doi.org/10.1016/j.compstruc.2011.05.022

Binda, L., Saisi, A. \& Tiraboschi, C. (2000). Investigation procedures for the diagnosis of historic masonries. Construction and Building Materials, 14,199-233. https://doi.org/10.1016/S0950-0618(00)00018-0

Cezar, M. \& Sertoğlu, M. (2011). Mufassal Osmanlı Tarihi, vol. 5, TTK publishing, Ankara, p. 2807-08.

Corradi, M., Borri, A. \& Vignoli, A. (2002). Experimental study on the determination of strength of masonry walls. Construction and Building Materials, 17, 5, 325-37. https://doi.org/10.1016/S095010-0618(03)00007-2

Cosgun, T, Sayin, B., Gunes, B., Avşar, A.O., Dönmezler, M., \& Acıoğlu, Y. (2019). The rejuvenation on historical ruined vaults using lab analyses and numerical simulation. Engineering Failure Analysis, 102, 270, 283. https://doi.org/10.1016/j.engfailanal.2019.04.046

Croci, G. (1998). The conservation and structural restoration of architectural heritage. Southampton: Computational Mechanics Publications.

Donnelly, J. (2010). The Conservation and repair of masonry ruins, Advice series.

Erişmiş, M.C. \& Gezerman, A.O. (2013). Rumeli fortress from the perspective of architecture history, Frontiers of Architectural Research, 2, $409-419$.

Feilden, B. (2003). Conservation of historic buildings. Oxford: Architectural press. Third edition.

Gabriel, A. (1941). İstanbul TürkKaleleri, A. Ilgaz (Trans.), 1001 TemelEser, Istanbul.

Heywood, S. (1982). The Ruined church at North Elmham, Journal of the British Archaeological Association,135,11, 1-10

Högg, H. (1932). Türkenburgenan Bosporus und Hellespont, Dresden, p.16-17 (in German)

Kritovulus, M. (1967). İstanbul'unFethi, M. Gökman (Trans.), Kapı publishing, Istanbul.

Mirmiroğlu, V.L. (1946). Fatih Donanmasıve Deniz Savaşları, Istanbul Belediyesi press.

MNK Restoration Co. (2017). The works of Restoration, Landscaping and Exhibition for Bigalı Castle.

Ostrogorsky, G. (1986). Bizans Devleti Tarihi, F. Işıltan (Trans.), TTK publishing, Ankara.

Povilaityte, E. (2016). The Conservation History, Problems and the Rehabilitation of Lithuanian Medieval Castles Procedia - Social and Behavioral Sciences 225, 85-95. https://doi.org/10.1016/j.sbspro.2016.06.011

Sevgen, N. (1959). AnadoluKaleleri, Doğuş Co., vol.1, Ankara.

Tiberti, S., Acito, M. \& Milani, G. (2016). Comprehensive FE numerical insight into Finale Emilia Castle behavior under 2012 Emilia Romagna seismic sequence: Damage causes and seismic vulnerability mitigation hypothesis, Engineering Structures, 117 , $397-421$. https://doi.org/10.1016/j.engstruct.2016.02.048 
TS EN 1926 (2013). Natural stone test methods-Determination of uniaxial compressive strength, Turkish Standards Institute, Ankara, Turkey.

TS EN 1936 (2010). Natural stone test methods-Determination of real density and apparent density and of total and open porosity, Turkish Standards Institute, Ankara, Turkey.

TS EN 12372 (2013). Natural stone test methods-Determination of flexural strength under concentrated load, Turkish Standards Institute, Ankara, Turkey.

TS 699 (2009). Natural building stones-Methods of inspection and laboratory testing, Turkish Standards Institute, Ankara, Turkey.

TS EN 14157 (2017). Natural stone test methods-Determination of the abrasion resistance, Turkish Standards Institute, Ankara, Turkey.

TS 10449/T1 (2004). Marble-calcium carbonate based-used for building and facing, Amendment 1, Turkish Standards Institute, Ankara, Turkey.

Uğurlu, E. (2009). Koruma Çalışmalarında Tarihi Harç ve Sıva Analizlerinin Önemi, MimarlıktaMalzeme. Journal of Material in Architectural, 4, 11, 8387, (in Turkish).

Utkular, I. (1954). Çanakkale Boğazında Fatih Kaleleri, iTü, Istanbul. 